\title{
WHAT TO EXPECT WHEN YOU'RE NO LONGER EXPECTING: HOW STATES USE CONCEALMENT AND ABUSE OF A CORPSE STATUTES AGAINST WOMEN
}

\author{
NISHA CHANDRA*
}

\begin{abstract}
Since the 1690s, women in the United States have been arrested and punished for experiencing miscarriages and stillbirths_pregnancy outcomes that are completely normal. This practice continues to the modern day, where prosecutors charge women with concealing a birth, concealing a death, or abuse of a corpse for the actions they take after experiencing pregnancy loss. This Note argues that these statutes were originally enacted to punish women who had sex outside of marriage and are now being used to control women, mostly women of color and poor women, for not adhering to society's idealized vision of femininity and motherhood. The use of these statutes advances notions of fetal personhood and will ultimately have a chilling effect on the availability of abortion through telemedicine. The Note suggests that while repealing these laws would help, the best solution is to approach the issue through a reproductive justice lensnamely, increasing the availability of education and medical services for women.
\end{abstract}

\section{INTRODUCTION}

One of the most heartbreaking events in a woman's life can be the loss of her pregnancy. ${ }^{1}$ The last thing she expects is that this loss can result in her being criminally charged and even jailed. Yet this outcome is a sad reality for numerous women who have experienced miscarriages or stillbirths. ${ }^{2}$ A miscarriage is defined as a loss of pregnancy before twenty weeks of gestation, whereas a stillbirth is a loss of pregnancy after twenty

\footnotetext{
* J.D. 2021, Columbia Law School; B.A. 2014, University of California, Berkeley. Special thanks to Professor Elizabeth Scott and Nancy Rosenbloom for their help and advice.

${ }^{1}$ Throughout this Note, I refer to the experiences of pregnant "women," for symmetry with language in the laws and brevity. However, these issues are not exclusive to cisgender women. There is also a very real threat that states may apply these same laws to trans men and gender non-conforming persons who may become pregnant.

${ }^{2}$ See infra Part I.D.
} 
weeks. ${ }^{3}$ Pregnancy loss is extremely common; one study estimated that, in total, about thirty-one percent of all pregnancies end before delivery. ${ }^{4}$ The Centers for Disease Control and Prevention (CDC) estimates that there are 24,000 stillbirths in the United States each year, or about 5.89 stillbirths per 1,000 births. ${ }^{5}$ However, it is often difficult to pinpoint the cause of a specific miscarriage or stillbirth. ${ }^{6}$ Even though both pregnancy and pregnancy loss are common and natural, a review found that between 1973 and 2005, there were at least 413 cases in the United States of pregnancy or pregnancy loss being the basis of an attempted or actual arrest, detention, or forced intervention. ${ }^{7}$ The majority of those cases involved allegations that the pregnant woman used illegal drugs while pregnant. ${ }^{8}$ But there is a subset of cases where women were charged not for their actions during pregnancy, but instead based on their post-birth actions. This Note discusses cases where women experienced a miscarriage or stillbirth and were later charged with the state crimes of concealing a birth or death, or a crime related to disposal of a corpse. It then explains the factors that may have led to these women's actions. Additionally, this Note argues the state's condemnation of their actions is based in disapproval of women who do not adhere to society's ideas of womanhood and advocates for a non-criminal approach to women who experience pregnancy loss.

Part I explores state laws regarding the concealment of births and deaths and discusses who is required to report stillbirths. It then explores state laws regarding abuse or improper disposal of a corpse. Part I then discusses the reasons why a woman may

\footnotetext{
${ }^{3}$ What Is Stillbirth?, CTRS. For Disease Control \& PREVEnTION, https://www.cdc.gov/ncbddd/stillbirth/facts.html [https://perma.cc/GD7S-68HV].

${ }^{4}$ Allen J. Wilcox et al., Incidence of Early Loss of Pregnancy, 319 New EnG. J. MED. 189, 191 (1988).

${ }^{5}$ Stillbirth: Data and Statistics, CTrs. For Disease Control \& Prevention, https://www.cdc.gov/ncbddd/stillbirth/data.html [https://perma.cc/JMU9-GNEF].

${ }^{6}$ Donna L. Hoyert \& Elizabeth C. W. Gregory, Cause of Fetal Death: Data from the Fetal Death Report, 2014, NaT'L Vital Stat. ReP., Oct. 31, 2016, at 4, https://www.cdc.gov/nchs/data/nvsr/nvsr65/nvsr65_07.pdf [https://perma.cc/QZ99-7YJS] (explaining that in this study, thirty percent of fetal deaths were due to an unspecified cause).

${ }^{7}$ The authors found 413 cases in the United States during this time period by reviewing published research, articles, and reports, and through involvement with and inquires to public defenders, other legal advocates, judges, and healthcare providers. They believe that this number is a substantial undercount. Lynn M. Paltrow \& Jeanne Flavin, Arrests of and Forced Interventions on Pregnant Women in the United States, 1973-2005: Implications for Women's Legal Status and Public Health, 38 J. HeAlth POL. POL'Y \& L. 299, 301-04, 30910 (2013).

${ }^{8} I d$.
} 
commit concealment or abuse of a corpse. Finally, Part I presents some case examples of women charged with these crimes. Part II analyzes how and why women of color and economically disadvantaged women are disproportionately charged with these crimes and examines the potential consequences for abortion access when these laws are applied to women experiencing normal pregnancy loss. Part III examines two potential alternatives - repealing these statutes or increasing education and access to healthcare - and concludes that a shift away from the legal system towards a social justice framework would be most successful.

\section{Background: Laws Against Concealing a Birth, Concealing a Death, and Abuse or Improper Disposal of a Corpse}

This Part explores the statutes prosecutors use to criminalize women's behavior during and after pregnancy loss. Part I.A.1 discusses how state laws criminalizing the concealment of births and deaths of a fetus were enacted to punish both infanticide and sex outside of marriage. Many of the current iterations of these laws still appear to have these goals. Part I.A.2 delves into the lack of clarity on when women must report their stillbirths. Part I.B examines how state laws criminalizing abuse of a corpse or improper disposal of a corpse were enacted for the benefit of public health and sensibilities. Finally, Part I.C explores the motivations women might have for concealing a birth or death or disposing of a corpse in secret, and Part I.D presents some examples of women who have been charged with these crimes.

\section{A. Concealment Statutes}

\section{The History and Purpose of These Statutes}

English law has a long history of punishing women for concealing a birth or concealing a death due to the suspicion that the woman had done something wrong. The connection between concealment and infanticide stretches at least back to the seventeenth century, where concealment of a dead newborn born out of wedlock was presumptive evidence of murder. ${ }^{9}$ England enacted the Act to Prevent the Destroying and Murdering of Bastard Children in 1624, which codified this presumption of murder. ${ }^{10}$ This Act, however, did not criminalize concealment of birth or death by married women because

\footnotetext{
${ }^{9}$ Lenora Ledwon, Maternity as a Legal Fiction: Infanticide and Sir Walter Scott's The Heart of Midlothian, 18 WOMEN's RTS. L. ReP. 1, 5 (1996).

${ }^{10}$ Joseph W. Dellapenna, Dispelling the Myths of Abortion History 100 (2006).
} 
these women were not assumed to have murderous intent. ${ }^{11}$ Many married women who did murder their children during this period were excused based on the defense of an impaired mental state, which would today be diagnosed as post-partum psychosis. ${ }^{12}$

The American colonies, carrying on English tradition, enacted statutes beginning in 1696 to punish the concealment of the birth or death of a bastard. ${ }^{13}$ Although the number of executions may likely be higher, surviving records for executions of women show that, in the eighteenth century, at least four women were executed in the United States for the crime of concealing a birth, with the last execution in $1785 .{ }^{14}$ These prohibitions continued after the Revolutionary War. ${ }^{15}$ A Massachusetts statute, adopted in 1785, began as follows:

An ACT to prevent the destroying and murdering of Bastard Children.

WHEREAS many lewd and dissolute women, being pregnant with bastard children, who, regardless of natural affection, and to avoid shame and escape punishment, do conceal their pregnancy, and the birth and death of such children, by means whereof many of them perish for want of necessary and usual assistance, and it cannot be known that they were not murdered. ${ }^{16}$

The language of the statute clearly indicates that the drafters were concerned about the state's inability to prove infanticide. ${ }^{17}$ But the references to "lewd and dissolute women" and "shame" also show that the state was reacting to the perceived moral
${ }^{11} I d$.
${ }^{12} I d$.
${ }^{13} I d$. at 116.
${ }^{14}$ ESPY File, Death Penalty Info. Ctr., EXecutions in the U.S. 1608-2002, EXeCutions by Date, https://deathpenaltyinfo.org/documents/ESPYyear.pdf [https://perma.cc/K9RS-NM9C]. Historians have determined that at least fifteen women were hung for the related crime of infanticide during roughly the same period in the colony of Massachusetts. See Dellapenna, supra note 10, at 115.
${ }^{15}$ Richard Chused \& Wendy Williams, Gendered Law in American History 290 (2016).
${ }^{16} I d$.
${ }^{17}$ Id. at 292. 
transgression of premarital sex. ${ }^{18}$ This connection was further bolstered when the Massachusetts law was codified in 1835, and the concealment provisions were placed in between provisions discussing fornication, polygamy, and prostitution. ${ }^{19}$ Legislatures of twelve other states connected concealment with abortion by enacting concealment statutes as part of or contemporaneously with abortion statutes. ${ }^{20}$

To this day, many states ${ }^{21}$ still have statutes in place that criminalize concealing either the birth or the death of a fetus. ${ }^{22}$ In Arkansas, a person is guilty of the felony of concealing a birth if they hide the corpse of a newborn child in order to conceal their birth or "prevent a determination of whether the child was born alive."23 Wisconsin's statute on concealing the death of a fetus specifically criminalizes "conceal[ing] the corpse of any issue of a woman's body with intent to prevent a determination of whether it was born dead or alive." ${ }^{24}$ The language of these statutes, along with those of other states ${ }^{25}$ indicates that these laws were intended to prosecute people who killed their newborns and concealed the fact that a birth or death took place. ${ }^{26}$

${ }^{18} I d$. at 291.

${ }^{19}$ Id. at 293; MASs. GEN. LAws ch. 272, § 22 (2020).

${ }^{20}$ DellapenNA, supra note 10, at 121.

${ }^{21}$ Some states with concealment laws include Georgia, Nevada, Oregon, Kentucky, New Hampshire, and Hawaii. See Ga. Code AnN. § 16-10-31 (2020); Nev. Rev. Stat. § 201.150 (2020); Or. Rev. Stat. § 167.820 (2020); Ky. Rev. Stat. AnN. § 530.030 (West 2020); N.H. Rev. Stat. ANN. § 639:5 (1973); Haw. REV. STAT. § 709-901 (2020).

${ }^{22}$ Statutes criminalizing the concealing of the death of a fetus specifically target behavior following natural pregnancy loss, as opposed to statutes criminalizing concealing the birth of a fetus, where there may not have been a natural pregnancy loss but instead may have been the murder of a newborn. This distinction is complicated somewhat by the Colorado statute, which applies to any person who conceals the death of another person, where "another person" includes a fetus born dead. CoLO. REV. STAT. § 18-8-109 (2020).

${ }^{23}$ ARK. CODE ANN. § 5-26-203 (2012).

${ }^{24}$ Wis. STAT. $§ 948.23$ (2014).

${ }^{25}$ See, e.g., 11 R.I. GEN. LAWS § 11-18-4 (2012).

${ }^{26}$ See, e.g., 18 PA. CONS. STAT. § 4303 (2016) (“A person is guilty of a misdemeanor of the first degree if he or she endeavors privately, either alone or by the procurement of others, to conceal the death of his or her child, so that it may not come to light, whether it was born dead or alive or whether it was murdered or not."); see also Мich. COMP. LAws $§ 750.150$ (2003) ("If any unmarried woman conceals the death of any issue of 
However, the laws do not specify the time period a woman has to inform someone of the birth before her actions are considered "hiding" or "concealing." ${ }^{27}$ These statutes also don't mention how developed the fetus must be before the statute is triggered. ${ }^{28}$ Women might miscarry very early on in their pregnancies, before they know they are pregnant, and mistake the miscarriage for a heavy period, ${ }^{29}$ but they still could be prosecuted for concealment. Additionally, these laws sometimes continue to rely on seventeenth century assumptions. The Rhode Island statute, for instance, was enacted in 1938 and applies only to concealing the birth of a child born out of wedlock, ${ }^{30}$ presumably because of the old theory that the shame of having a child out of wedlock might drive a woman to feticide. ${ }^{31}$

Laws criminalizing the concealment of the birth or death of a fetus seem primarily concerned with people hiding that a newborn died due to homicide, with perhaps a secondary intention to prevent the public health consequences of improper disposal of human remains. ${ }^{32}$ Some of these laws do not appear to have been enacted in order to

her body, so that it may not be known whether such issue was born alive or not, or whether it was not murdered, she shall be punished by a fine not exceeding $\$ 1,000.00$ or imprisonment for not more than 1 year.").

${ }^{27}$ See supra notes $22-26$ and accompanying text.

${ }^{28}$ For instance, Michigan's statute uses the phrase "any issue of her body" and does not require the "issue" to have any recognizable human characteristics. МicH. CoMP. LAws $§ 750.150$. Therefore, the law could conceivably apply to a miscarriage consisting of a small amount of tissue. Wisconsin similarly criminalizes the concealment of "the corpse of any issue of a woman's body" without any explanation of when a miscarriage or stillbirth is considered a corpse. WIS. STAT. § 948.23.

${ }^{29}$ Signs of Miscarriage, AM. PregnANCY Ass'N, https://americanpregnancy.org/pregnancycomplications/miscarriage/ [https://perma.cc/MJ27-LPPK] (discussing how a woman might experience a chemical pregnancy, where "a pregnancy is lost shortly after implantation, resulting in bleeding that occurs around the time of her expected period").

3011 R.I. GEN. LAWS $§ 11-18-4$.

${ }^{31}$ See supra notes $11-12$ and accompanying text.

${ }^{32}$ See, e.g., Dellis v. Commonwealth, No. 0341-17-3, 2018 Va. App. LEXIS 109, at*9 (Va. Ct. App. Apr. 24,2018 ) ("To find that the remains of a fetus do not raise the same public health concerns as other recently deceased human remains would be an irreconcilable proposition.”). 
punish women who experienced normal miscarriages or stillbirths. ${ }^{33}$ But they may have this unintended consequence, in part because they do not set out a reporting timeline women must meet before their actions are considered "concealment."

\section{Miscarriage and Stillbirth Reporting Requirements}

The Model State Vital Statistics Act and Regulations (Regulations) provides guidance to states on how to collect data on vital statistics, ${ }^{35}$ which includes data about births, deaths, terminations of pregnancy, marriages, and divorces. ${ }^{36}$ The Regulations, issued by the U.S. Department of Health and Human Services, were created to "promote uniformity among States in definitions, registration practices, disclosure and issuance procedures, and in many other functions that comprise a State system of vital statistics."${ }^{, 37}$ As a part of this mission, the Regulations specify requirements for the reporting of fetal death. ${ }^{38}$ Specifically, the Regulations recommend that fetal deaths of over 350 grams or over twenty weeks of gestation be reported within five days of delivery to the Office of Vital Statistics or as otherwise directed by the State Registrar. ${ }^{39}$ When fetal death occurs without medical attendance at or immediately after delivery, the medical examiner or coroner who investigates the cause of fetal death is tasked with filing the report. ${ }^{40}$ The Regulations do not place any burden on the woman who has experienced the stillbirth to report the birth to the appropriate office or to a medical professional. ${ }^{41}$ Many states have

\footnotetext{
${ }^{33}$ See, e.g., Opinion Letter No. 18-023 from Mark R. Herring, Att'y Gen. of Va., to Ralph S. Northam, Governor of Va. (May 25, 2018), https://www.oag.state.va.us/files/Opinions/2018/18-023-Northam-officialopinion.pdf [https://perma.cc/25PL-JYFM] (stating that Virginia's concealment of a dead body statute was not intended to apply to concealment of a human fetus that expired in utero).

${ }^{34}$ See, e.g., Мich. СомP. LAws $§ 750.150$ (2003).

${ }^{35}$ Nat'l C Ctr. for Health Stat., Ctrs. for Disease Control \& Prevention, Model State Vital STATISTICS ACT AND REGUlATIONS, at iii (1992), https://www.cdc.gov/nchs/data/misc/mvsact92b.pdf [https://perma.cc/M5MK-WG5P].

${ }^{36} I d$. at 2.

${ }^{37}$ Id. at iii.

${ }^{38} I d$. at 8.

${ }^{39} \mathrm{Id}$.

${ }^{40} I d$.

${ }^{41} I d$.
} 
adopted their own Vital Statistics Acts that specify fetal death reporting requirements for healthcare professionals with language that mirrors that used in the Regulations. ${ }^{42}$ Some state laws are more stringent than the Regulations, such as the Oklahoma law, which requires a report of fetal deaths at twelve weeks of gestation or beyond. ${ }^{43}$

A few states, though, have enacted laws which specifically require laypeople to report stillbirths. In North Dakota, it is a misdemeanor for a person to conceal a stillbirth or fail to report the death of an infant under the age of two to a physician or county coroner. ${ }^{44}$ In Oklahoma, it is a crime for a woman to endeavor to conceal her stillbirth, but only if the fetus would have been a "bastard" if born alive. ${ }^{45}$ The Court of Criminal Appeals of Oklahoma ruled that it was not an equal protection violation to put this burden of reporting solely on women. ${ }^{46}$ These statutes don't specify how long a person has to report a stillbirth or, in some cases, don't specify to whom the stillbirth should be reported. ${ }^{47}$ This makes it difficult for women to comply with state reporting requirements, assuming they were aware of the requirements in the first place.

\section{B. Abuse and Disposal of a Corpse Statutes}

Abuse and disposal of a corpse statutes differ from concealment statutes in that their original purpose is not focused on the potential murder of a newborn child. For instance, the Model Penal Code states that it is a misdemeanor for a person to "treat a corpse in a way that he knows would outrage ordinary family sensibilities," unless authorized by law. ${ }^{48}$ This code section is primarily focused on feelings of outrage by the surviving kin

\footnotetext{
42 See, e.g., IDAHO CODE $\S \S 39-240,39-260$ (2014); N.C. GEN. STAT. § 130A-114 (2011); see also Hoyert \& Gregory, supra note 6, at 4 ("The majority of areas require reporting of fetal deaths at 20 weeks of gestation or more, at a minimum birthweight of 350 grams (roughly equivalent to 20 weeks), or some combination of the two. However, several areas require reporting of fetal deaths at all periods of gestation, and one area requires reporting beginning at 16 weeks of gestation.").

${ }^{43}$ OKLA. STAT. tit. 63, § 1-301 (2020).

${ }^{44}$ N.D. CENT. CODE $§ 14-02.1-10$ (2019).

${ }^{45}$ OKLa. Stat. tit. 21, § 863 (2020).

${ }^{46}$ State v. Johnson, 765 P.2d 1226, 1229 (Okla. Crim. App. 1988) ("Insofar as the mother will inevitably be present when her child is stillborn, it is completely logical that the mother is the person charged with the responsibility of reporting the death to the proper authorities.").

${ }^{47}$ See, e.g., N.D. CENT. CODE $§ 14-02.1-10$.

${ }^{48}$ Model Penal Code $§ 250.10(1980)$.
} 
upon learning what happened to the corpse of a relative, which most often arises from actions such as mutilation, gross neglect, or sexual abuse of the deceased. ${ }^{49}$ Fourteen states have abuse of a corpse statutes that are modeled on this code section. ${ }^{50}$ The language in these statutes contains a knowledge requirement for the alleged corpseabuser's state of mind - they must know that their actions would outrage ordinary sensibility. ${ }^{51}$

Often, the purpose of laws prohibiting the mistreatment of dead bodies is to prevent public indignation. ${ }^{52}$ Statutes regarding abuse or disposal of corpses have been challenged as being unconstitutionally vague, ${ }^{53}$ likely because the kinds of behavior that cause outrage may vary tremendously, and people may not know what behaviors they must not engage in so as to avoid violating the statute. However, courts in Pennsylvania, Ohio, and Arkansas have upheld the statutes against claims of vagueness. ${ }^{54}$ In an Iowa case involving the disposal of a stillborn fetus, the court ruled that the language in a statute that criminalized the "indecent exposure" of a human body was unconstitutionally vague, but the court upheld the statute as a whole. ${ }^{55}$

In some instances, courts have broadened the scope of what constitutes "abuse" of a corpse beyond just perverse acts which would clearly offend society. This expansion has

49 John S. Herbrand, Annotation, Validity, Construction, and Application of Statutes Making It a Criminal
Offense to Mistreat or Wrongfully Dispose of Dead Body, 81 A.L.R.3d 1071 § 2a (1977).

${ }^{50}$ Khushbu Solanki, Buried, Cremated, Defleshed by Buzzards? Religiously Motivated Excarnatory Funeral Practices Are Not Abuse of Corpse, 18 RuTGERs J.L. \& RELIGION 350, 365 (2017).

${ }^{51} I d$.

${ }^{52}$ Herbrand, supra note $49, \S 2 \mathrm{a}$.

${ }^{53}$ Commonwealth v. Smith, 567 A.2d 1070, 1073 (Pa. Super. Ct. 1989) (finding that "the purpose of drafting [Pennsylvania's] abuse of corpse statute in very broad and general language was to ensure that offenses such as concealing a corpse came under the purview of the statute"); State v. Glover, 479 N.E.2d 901, 904 (Ohio Ct. App. 1984) (finding that the Ohio statute was not unconstitutionally vague because "[t]he words, 'treat,' 'human corpse,' 'way,' 'outrages,' and 'sensibilities' are commonly understood by persons of common intelligence”); Dougan v. State, 912 S.W.2d 400, 404 (Ark. 1995) (finding that Arkansas' abuse of a corpse statute "conveys fair and sufficient warning when measured by common understanding").

${ }^{54}$ Supra note 53.

${ }^{55}$ State v. Aldrich, 231 N.W.2d 890, 895 (Iowa 1975) (discussing Iowa Code $§ 714.22$, which at the time read: "If any person willfully and unnecessarily, and in an improper manner, indecently expose, throw away, or abandon any human body, or the remains thereof, in any public place, or in any river, stream, pond, or other place, he shall be imprisoned or be fined."). 
been used to prosecute women who simply dispose of the remains of their pregnancy. In Arkansas ${ }^{56}$ a woman was charged with abuse of a corpse when she wrapped her stillborn fetus in a sheet and threw it out in a dumpster. ${ }^{57}$ On appeal, the court ruled that placing the corpse in a dumpster "constitutes a form of mishandling, abuse, or neglect [and] the jury could have concluded that [the defendant's] conduct amounted to physical mistreatment of a corpse in a manner offensive to a person of reasonable sensibilities." Shielded by expansions of this kind, states may be using abuse of a corpse statutes against women who have suffered a normal pregnancy loss and have committed no crime other than disposing of the fetus in an improper way. ${ }^{59}$

\section{Why Women Might Conceal a Miscarriage or Stillbirth}

In some of these cases, the women who were charged had not told anyone that they were pregnant, and prosecutors used this fact as evidence that they did not want to be pregnant and had committed some crime as a result. ${ }^{60}$ However, women may conceal their pregnancy and subsequent miscarriage or stillbirth from family and friends for other reasons. Women are often advised to wait to disclose their pregnancy until they have passed their first trimester so that they do not have to go through the pain of telling people if they suffer a miscarriage. ${ }^{61}$ Others conceal their pregnancy for a variety of different factors, such as social shame over falling pregnant, fear of abandonment, or a perceived lack of support. ${ }^{62}$ Because women who conceal their pregnancy are less likely to receive prenatal medical care, they are also more likely to experience childbirth

\footnotetext{
${ }^{56}$ Ark. Code AnN. § 5-60-101 (2012).

${ }^{57}$ Dougan, 912 S.W.2d at 401.

${ }^{58} I d$. at 405.

${ }^{59}$ See infra Part I.D.

${ }^{60}$ See infra Part I.D.

${ }^{61}$ Evonne Lack, When to Announce Your Pregnancy, BABYCEnTER (Jan. 22, 2019), https://www.babycenter.com/pregnancy/preparing-for-baby/when-to-announce-your-pregnancy_10349769 ("One mom offers this cautionary tale: 'I got pregnant and announced it at work right away, then miscarried over Thanksgiving. When I came back to work, people kept dropping by my office to congratulate me. It was very sad and awkward."”).

${ }^{62}$ Sylvia Murphy Tighe \& Joan G. Lalor, Concealed Pregnancy: A Concept Analysis, 72 J. Advanced NURSING 50, 54-55 (2016).
} 
complications or pregnancy loss. ${ }^{63}$ Concealment of a pregnancy does not necessarily mean that a woman will try to induce a pregnancy loss. Even if a pregnancy was unplanned or unwanted, losing the pregnancy through a miscarriage or stillbirth can be highly traumatic, and women may experience extreme shock, which can affect their actions after the pregnancy loss. ${ }^{64}$ Women who have experienced stillbirths have significantly higher rates of psychological and emotional disorders such as post-traumatic stress disorder. ${ }^{65}$ Many experience negative mental health effects, like feeling guilty for not being able to save their baby ${ }^{66}$ For women who had concealed their pregnancy and suffered through a miscarriage or stillbirth alone, it may be psychologically and practically easier to pretend the pregnancy never happened. ${ }^{67}$ Additionally, because reporting requirements vary by state, a woman may simply not be aware of her legal obligations after having a miscarriage or stillbirth. ${ }^{68}$

Even women who are not concealing their pregnancy might not seek out medical care when going into labor or after labor because of the associated costs. Data from the United States Census Bureau indicates that $12.2 \%$ of women were uninsured in $2018 .^{69}$ This large portion of women would have to bear all of their medical costs if they sought medical care after pregnancy loss. This medical care is expensive; indeed, costs for stillbirths are ten to seventy percent more expensive than costs for live births. ${ }^{70}$ The cost

${ }^{63} I d$. at 51 .

${ }^{64}$ Kalandary Lacy, when asked why she put her miscarried fetus in a dumpster, replied, "I can't give you an answer to why I did it. I was just in shock." State v. Lacy, No. W2016-00837-CCA-R3-CD, 2017 Tenn.

Crim. App. LEXIS 375, at*4-5 (Tenn. Crim. App. May 12, 2017).

${ }^{65}$ Christy Burden et al., From Grief, Guilt Pain and Stigma to Hope and Pride-A Systematic Review and Meta-Analysis of Mixed-Method Research of the Psychosocial Impact of Stillbirth, 16 BMC PREGNANCY \& CHILDBIRTH 1, 3-4 (2016), https://bmcpregnancychildbirth.biomedcentral.com/articles/10.1186/s12884-0160800-8 [https://perma.cc/9KPE-MEZ6].

${ }^{66}$ Alexander E. P. Heazell et al., Stillbirths: Economic and Psychosocial Consequences, 387 LANCET 604, 606 (2016).

${ }^{67}$ See, e.g., Susana Kuehne, I Had a Miscarriage at Work and Pretended Nothing Happened, SCARYMommY (Jan. 3, 2018), https://www.scarymommy.com/miscarriage-at-work/ [https://perma.cc/2EQB-G5AE].

${ }^{68}$ See supra Part I.A.2.

${ }^{69}$ Health of Women and Children-Uninsured Women, United HeALTH Found. (2019), https://www.americashealthrankings.org/explore/health-of-women-andchildren/measure/Uninsured_women/state/ALL [https://perma.cc/WLY6-SKF3].

${ }^{70}$ Heazell et al., supra note 66, at 604 . 
of having a stillbirth in a hospital can range from $\$ 659$ to $\$ 77,080$, with a median cost of $\$ 5,977 .{ }^{71}$ Women may also have to pay between $\$ 197$ and $\$ 3,093$ for investigations to identify the cause of the stillbirth and $\$ 118$ to $\$ 20,000$ in hospital fees for additional medical care. ${ }^{72}$ Women may choose to stay home during labor to avoid these costs and not know what to do when they experience a miscarriage or stillbirth. Even going to the hospital after experiencing a pregnancy loss at home can be costly, so it is likely that women may choose not to go, especially if their labor was unproblematic and without any lasting effects.

Women may also be disincentivized from seeking medical care or being honest with their doctors after a miscarriage or stillbirth because of a mistrust of the medical system. Many people, especially people of color, have a high level of distrust of medical professionals. ${ }^{73}$ This distrust is not unfounded. Indeed, as the cases discussed in Part I.D show, women are sometimes arrested after pregnancy loss because a physician reported them to law enforcement. ${ }^{74}$ In one instance, a doctor called the cops on a patient who went to the emergency room after falling down a flight of stairs while pregnant, believing that the woman purposely fell in order to harm her fetus. The woman was arrested but was eventually released because her pregnancy was not yet in its third trimester at the time of her fall and therefore was not covered by the state's feticide law. ${ }^{75}$ Although courts have found that there exists a fiduciary relationship between doctors and their patients ${ }^{76}$ there are many examples of this trust being broken by doctors, especially when the patient is a pregnant woman. ${ }^{77}$ In South Carolina, a prosecutor started a task force

\footnotetext{
${ }^{71}$ Katherine J. Gold et al., Hospital Costs Associated with Stillbirth Delivery, 17 Maternal Child Health J. 1835,1838 (2013).

${ }^{72}$ Heazell et al., supra note 66, at 605.

${ }^{73}$ Katrina Armstrong et al., Racial/Ethnic Differences in Physician Distrust in the United States, 97 Am. J. Pub. Health 1283, 1287 (2007).

${ }^{74}$ See infra Part I.D.

${ }^{75}$ Kevin Hayes, Did Christine Taylor Take Abortion into Her Own Hands?, CBS News (Mar. 2, 2010), https://www.cbsnews.com/news/did-christine-taylor-take-abortion-into-her-own-hands/ [https://perma.cc/MF8N-UY4F].

${ }^{76}$ Michele Goodwin, Fetal Protection Laws: Moral Panic and the New Constitutional Battlefront, 102 CALIF. L. REV. 781, 820 (2014).

77 See, e.g., USF Obstetrician Threatens to Call Police if Patient Doesn't Report for C-section, TAMPA BAY TIMES (Mar. 6, 2013), https://www.tampabay.com/news/health/usf-obstetrician-threatens-to-call-police-ifpatient-doesnt-report-for/2107387 [https://perma.cc/2NJ9-M697].
} 
with healthcare providers and trained them on how to obtain evidence against pregnant women seeking prenatal care and how to report these women to the police. ${ }^{78}$ Through this program, pregnant women who were admitted to the hospital were selectively drug tested by hospital staff without their consent, and those who tested positive were reported to authorities and in some cases, chained to their hospital beds during birth. ${ }^{79}$ Actions like these create a law enforcement role for medical providers that encourages them to prioritize their legal judgments over their medical duty to their patients. This phenomenon will only further the suspicion certain groups of women feel towards healthcare providers and will likely disincentivize them from seeking out medical care in the future.

\section{Case Studies}

The following examples show the varied circumstances under which women can be arrested for concealment or abuse of a corpse. These cases raise questions about what other actions the women could have taken after experiencing pregnancy loss to avoid their arrest and the benefits of criminally punishing women for these crimes.

Anne Bynum was living with her mother in 2015 when she found out she was pregnant. ${ }^{80}$ Bynum concealed the pregnancy from her mother out of fear that she would be asked to move out, but told friends, her priest, and her lawyer. ${ }^{81}$ She was also in the process of finding someone to adopt the baby. ${ }^{82} \mathrm{~A}$ few days after taking medication to induce labor, Bynum had a stillbirth in the middle of the night at her mother's Arkansas home. ${ }^{83}$ Bynum cleaned up and put the remains of the stillbirth in her car, but she felt too lightheaded to drive and went back to sleep. ${ }^{84}$ She texted her lawyer about what happened

\footnotetext{
${ }^{78}$ Goodwin, supra note 76 , at $825-26$.

${ }^{79}$ Yesenia M. Perez, Ferguson v. City of Charleston and Criminalizing Drug Use During Pregnancy, 15 Am. Med. Ass'N J. Ethics 771, 771-72 (2013).

${ }^{80}$ Bynum v. State, 546 S.W.3d 533, 536 (Ark. Ct. App. 2018).

${ }^{81} I d$.

${ }^{82} I d$.

${ }^{83} \mathrm{Id}$. at 537.

${ }^{84} \mathrm{Id}$.
} 
the next morning and followed her lawyer's advice to bring the remains to a hospital. ${ }^{85}$ Testing confirmed the fetus was stillborn. ${ }^{86}$ Bynum was convicted of concealing a birth, ostensibly because she put the remains in her car in order to conceal the stillbirth from her mother. ${ }^{87}$ While her conviction was later overturned on procedural grounds, ${ }^{88}$ the court noted on appeal that the statute under which Bynum was convicted "does not specify how long a newborn's corpse must be concealed to be found guilty of this offense, nor does it provide for the prospect that a person can conceal a birth by hiding the corpse temporarily but then can be exempt from the statute's dictates if he or she reveals the birth to a person a few hours later. ${ }^{89}$

Katherine Dellis lost consciousness as she went into labor in the bathroom of her Virginia home at about 30 weeks of gestation. ${ }^{90}$ She awoke to find a stillborn fetus, which she put in a trash bag and left in the bathroom. ${ }^{91}$ Her father did not know what was in the trash bag and later threw it out in a public dumpster. ${ }^{92}$ Dellis went to the emergency room after labor and told her treating physician what happened. ${ }^{93}$ The physician called the police. ${ }^{94}$ Testing by the medical examiner revealed that the fetus' lungs had never been exposed to air, and he therefore concluded that the fetus died in utero, "less than several days" before Dellis gave birth. ${ }^{95}$ She was charged with concealing a dead body. ${ }^{96}$ She entered a conditional guilty plea but later appealed, arguing that a stillborn fetus did not

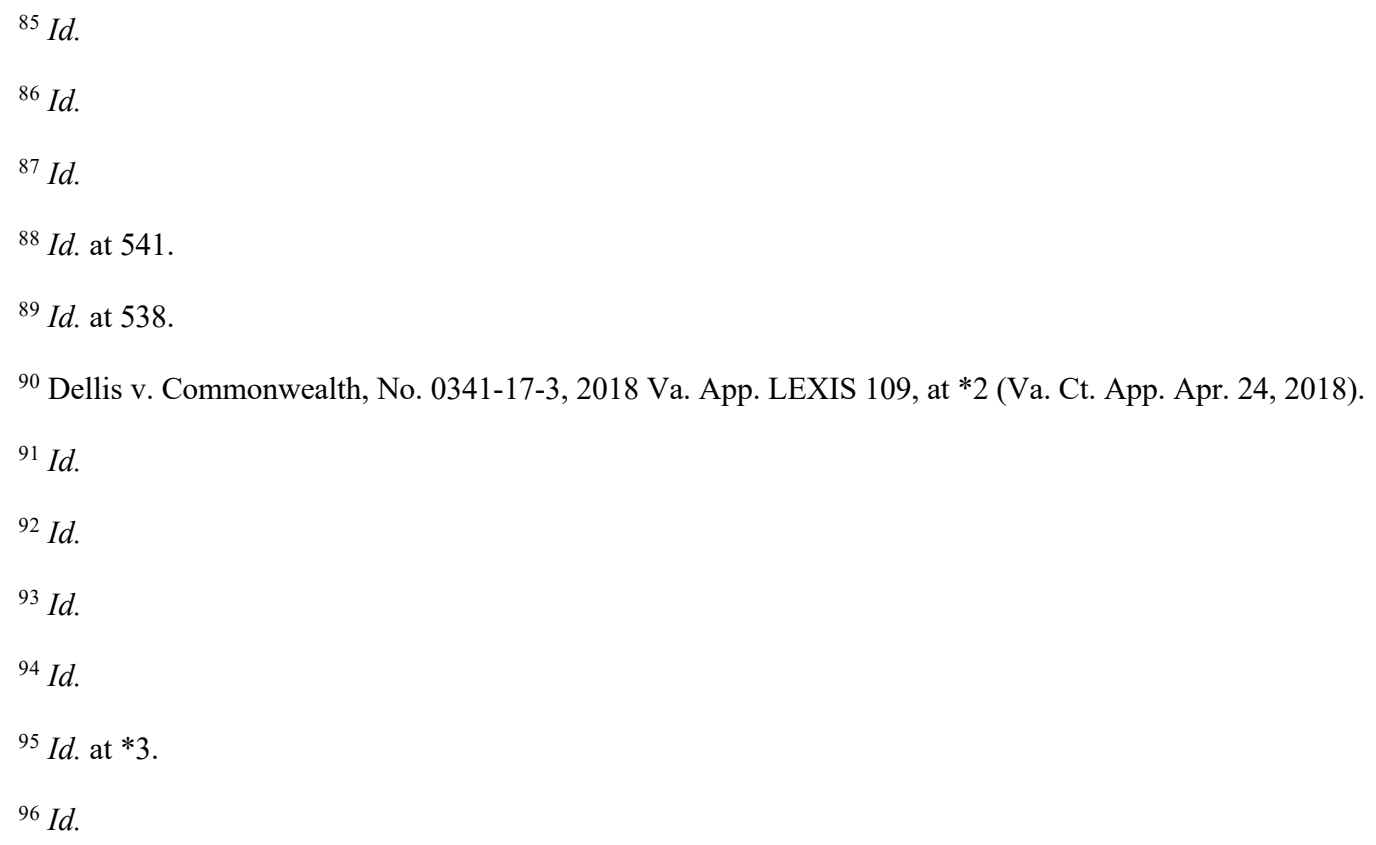


fall within the definition of a "dead body." ${ }^{97}$ The appeals court rejected this argument and affirmed her conviction. ${ }^{98}$

Michelle Marie Greenup went to the hospital because she was experiencing bleeding and stomach pain. ${ }^{99}$ Her doctor thought she may have recently given birth and contacted law enforcement. ${ }^{100}$ After an interrogation, Greenup "admitted" to giving birth to a live baby that had died because she did not provide adequate care. ${ }^{101}$ Greenup was incarcerated on charges of second-degree murder before her lawyer was able to obtain her medical records. These records showed that Greenup was, at most, eleven to fifteen weeks pregnant at the time of labor, so the fetus was likely not viable, ${ }^{102}$ and that she had been prescribed a form of birth control that may have caused a miscarriage. ${ }^{103}$ She was released from custody, but only after pleading guilty to improper disposal of human remains. ${ }^{104}$

\footnotetext{
${ }^{97}$ Id. at $* 4$. D2F9].

${ }^{99}$ Paltrow \& Flavin, supra note 7, at 308-09.

${ }^{100} I d$. at 308 .

${ }^{101} I d$.
}

${ }^{98} I d$. at $* 1$. Dellis was subsequently pardoned by the governor of Virginia. Justin Jouvenal, Va. Governor Pardons Woman Convicted of Disposing of Stillborn Fetus, WASH. PosT (June 1, 2018), https://www.washingtonpost.com/local/public-safety/va-governor-pardons-woman-convicted-of-disposingof-stillborn-fetus/2018/06/01/8ec206be-6ed0-4ebc-ae16-ff835f9e202a_story.html [https://perma.cc/BF9G-

${ }^{102}$ A pregnancy loss at this stage would be defined as a miscarriage. See supra text accompanying note 3 . It is extremely unlikely that the fetus Greenup delivered would have been viable outside the womb at eleven to fifteen weeks of gestation, even if it had been born alive. Only about three to five percent of infants born at the much later stage of twenty-two weeks of gestation survive. Matthew A. Rysavy et al., Between-Hospital Variation in Treatment and Outcomes in Extremely Preterm Infants, 372 NEw ENG. J. MED. 1801, 1801 (2015) (stating that "overall rates of survival and survival without severe impairment ranged from 5.1\% . . and $3.4 \%$ respectively, among children born at 22 weeks of gestation").

${ }^{103}$ Paltrow \& Flavin, supra note 7, at 309.

${ }^{104} I d$. 
Keyshonna Reed, a mother of three, woke up in the middle of the night with stomach pains. ${ }^{105}$ She gave birth to twins in her bathtub, both of whom she said were not breathing. ${ }^{106}$ Her family and the babies' father were not aware that she was pregnant. ${ }^{107}$ In a moment of panic, she placed the remains in a suitcase and left it on the side of the road. ${ }^{108}$ When the police found the suitcase and asked the public for information, Reed turned herself in. ${ }^{109}$ Testing confirmed that the babies died in the womb, and Reed was charged with abuse of a corpse. ${ }^{110}$

\section{The Rationale for and Consequences of Criminalizing These Acts}

Part II.A explores how modern technology may have rendered concealment statutes superfluous, and that states may now be using them to punish women for behavior that does not fit societal expectations. Part II.B continues to discuss how women of color and low-income women are disproportionately affected by these laws, both because they have higher rates of stillbirths and because they are vulnerable to stereotyping by healthcare professionals, law enforcement, and prosecutors. Part II.C discusses how use of these laws to protect fetuses advances fetal personhood ideals, which has negative implications for women's autonomy. Finally, Part II.D speculates that the incidence of women being charged with these crimes will rise with the increased availability of telemedicine, specifically the increased access to medication abortion.

\footnotetext{
105 Editorial Board, When Prosecutors Jail a Woman for a Miscarriage, N.Y. TIMES (Dec. 28, 2018), https:/www.nytimes.com/interactive/2018/12/28/opinion/abortion-pregnancy-pro-life.html [https://perma.cc/4XC9-R33T].

$106 \mathrm{Id}$.

107 Woman Accused of Discarding Stillborn Twins Said She “Panicked, ” KaIT8 (Mar. 23, 2018), https://www.kait8.com/story/37797272/woman-accused-of-discarding-stillborn-twins-said-she-panicked/ [https://perma.cc/3WUE-BFNC].

${ }^{108}$ Id.

${ }^{109}$ Editorial Board, supra note 105.

${ }^{110} I d$.
} 


\section{A. Use of Concealment Crimes When No Other Crime Can Be Proved}

During the period when concealment statutes were originally enacted, it was sometimes difficult to determine whether a child was born alive or stillborn. ${ }^{111}$ Medical knowledge was far less advanced than it is today; for instance, it was only by 1830 that books with accurate descriptions of fetal development became available in the United States. ${ }^{112}$ Around this time, fetal autopsies could sometimes be used to determine whether the lungs of the fetus had been inflated, but as a Pennsylvania court pointed out in an infanticide case, often there was no way of knowing whether breaths were taken before or after the child was completely born. ${ }^{113}$ The state had to show that the child's lungs had been inflated after the child was completely born in order to show that the child had been alive outside the womb and therefore that the death was not due to a normal complication during pregnancy or birth. ${ }^{114}$ Because concealment crimes did not require proof of a live birth, prosecutors historically used these crimes as a stopgap to charge women suspected of crimes like infanticide when there was a lack of evidence of that crime. ${ }^{115}$

Today, however, use of this stopgap is unnecessary. For cases of suspected infanticide, law enforcement can use testing to determine a fetus's approximate time and cause of death. ${ }^{116}$ Doctors can examine either the fetal tissue or placenta and use many different factors to determine details of the fetus's death. ${ }^{117}$ This can allow a conclusion to be drawn about whether there was a fetal death in utero or whether there was a live birth after which the child perished. These advances in technology have rendered the use of concealment crimes unnecessary in those cases where doctors can conclusively determine whether or not infanticide has occurred. Of course, these techniques are not foolproof and should be used in addition to other evidence to determine whether the baby

\footnotetext{
${ }^{111}$ Chused \& Williams, supra note 15, at 292.

${ }^{112} I d$. at 340 .

${ }^{113}$ Id. at $292-93$.

${ }^{114} I d$.

${ }^{115}$ D. Seaborne Davies, Child-Killing in English Law, 1 Mod. L. Rev. 203, 213 (1937).

${ }^{116}$ See, e.g., Dellis v. Commonwealth, No. 0341-17-3, 2018 Va. App. LEXIS 109, at*3 (Va. Ct. App. Apr. 24, 2018) ("[The Medical Examiner] testified that a physical examination of specific characteristics allowed him to determine when and how the fetus died.").
}

${ }^{117}$ David R. Genest, Estimating the Time of Death in Stillborn Fetuses: II. Histologic Evaluation of the Placenta; A Study of 71 Stillborns, 80 Am. J. Obstetrics \& GyneCology 585, 585 (1992). 
was born alive and passed away or if the woman has experienced a normal pregnancy loss. ${ }^{118}$

Although these concealment crimes are largely obsolete, states continue to use them against women, even in situations where testing can definitively prove that the woman experienced a miscarriage or stillbirth. ${ }^{119}$ In some cases where the woman has in fact experienced a normal pregnancy loss, law enforcement and prosecutors, whether consciously or unconsciously, may be using these statutes as a way to punish women for behavior deemed "socially undesirable." Even when they were first enacted in the United States, concealment laws were partially used as a means of showing disapproval towards and punishing certain women. ${ }^{120}$ Early concealment laws were focused solely on unmarried women who experienced pregnancy loss, in part because of the societal disapproval of sex outside of marriage. ${ }^{121}$

Deterring infanticide was likely not the sole purpose of these targeted laws; historians have concluded, based on the scarcity of records, that infanticide was not common in colonial America, perhaps because children were a needed resource in the sparsely populated land. ${ }^{122}$ But the crime of "fornication" was a very large concern in the American colonies, and one that colonial governments were eager to prosecute. ${ }^{123}$ In fact, records for Middlesex County, Massachusetts, show that fornication was the most commonly charged crime between 1760 and $1774 .{ }^{124}$ Because of this concern regarding out-of-wedlock sexual activity, early state concealment statutes can be understood partly as a mechanism to punish pregnant unmarried women for their sexual activities rather than solely as a way to punish infanticide. Even to this day, some state statutes single out

\footnotetext{
${ }^{118}$ Purvi Patel was incarcerated for feticide after she reported her stillbirth to a hospital. During the trial, the medical examiner testified that he used a lung flotation test and was able to determine that the fetus was born alive. However, many medical professionals feel that this test has been discredited and should not be used in a criminal trial. Leon Neyfakh, False Certainty, SLATE (Feb. 5, 2015), https://slate.com/news-andpolitics/2015/02/purvi-patel-feticide-why-did-the-pathologist-use-the-discredited-lung-float-test.html [https://perma.cc/V2VQ-QBCA].

${ }^{119}$ See supra Part I.D.

${ }^{120}$ See ChuSED \& WilLiams, supra notes $15-18$ and accompanying text.

${ }^{121}$ See CHUSED \& WiLLIAMS, supra notes 18-19 and accompanying text.

${ }^{122}$ DellapenNa, supra note 10, at 110.

${ }^{123} \mathrm{Id}$. at 111.

${ }^{124} \mathrm{Id}$.
} 
and criminalize concealment of the birth or death of a fetus only if that fetus would have been born out of wedlock had it been born alive. ${ }^{125}$ Through statutes like these, women who have sex outside of marriage and fall pregnant can be criminally liable in ways that married women who perform the same acts cannot be.

The unspoken justification for these laws may also have transformed over timefrom punishing women for infanticide and fornication, to punishing women for not fitting into an idealized model of femininity. ${ }^{126}$ The idea of womanhood in our society is tied to the idea of motherhood; becoming a mother is seen as the overarching and defining purpose of a woman's life. ${ }^{127}$ Girls are thought to become women at puberty, implying that the ability to reproduce is an essential part of being a woman. ${ }^{128}$ Those who delay having children or do not have children at all are thought of as selfish or not "real" women. ${ }^{129}$ Women are assumed to be inherently nurturing and self-sacrificing individuals, especially towards their offspring. ${ }^{130}$ These norms dictate that women find parenting to be a stress-free and enjoyable experience and be highly involved parents. ${ }^{131}$ Even women with successful careers are expected to sacrifice their jobs to stay at home and spend their efforts raising their children because that is their role as women. ${ }^{132}$ Through these norms, working mothers are made to feel guilty for being "bad" mothers.

\footnotetext{
${ }^{125}$ See, e.g., 11 R.I. GEN. LAWS $§ 11-18-4$ (2012); see also OKLA. STAT. tit. 21, § 863 (2020).

${ }^{126}$ Reva Siegel notes how a similar shift in justification occurred with relation to laws about domestic abuse. Until the late nineteenth century, the common law dictated that women were seen as the property of their husbands, or subordinate to them in the way a child was, and so "chastisement" was justified. Reva B. Siegel, The Rule of Love: Wife Beating as Prerogative and Privacy, 105 YALE L.J. 2117, 2121-22 (1996). Over time, the state instead declined to get involved in many situations of domestic abuse with the justification of the respect for "marital privacy." Id. at 2154.
}

${ }^{127}$ M. M. Slaughter, The Legal Construction of "Mother," in Mothers in Law: Feminist Theory AND the Legal Regulation OF MOTHERHOOD 74 (Martha Albertson Fineman \& Isabel Karpin eds., 1995).

${ }^{128}$ Joan C. Chrisler, Womanhood Is Not as Easy as It Seems: Femininity Requires Both Achievement and Restraint, 14 Psych. Men \& Masculinity 117, 117 (2013).

${ }^{129} \mathrm{Id}$. at 118 .

${ }^{130}$ Paula Abrams, The Bad Mother: Stigma, Abortion and Surrogacy, 43 J.L. MED. \& ETHICs 179, 180 (2015) (discussing how "conception is assumed to begin a process that inevitably leads to gestation and nurturance; the social identity of women has been shaped by the expectation that women are "natural' nurturers.").

${ }^{131}$ Chrisler, supra note 128 , at 118.

${ }^{132}$ Harmony D. Newman \& Angela C. Henderson, The Modern Mystique: Institutional Mediation of Hegemonic Motherhood, 84 SocIO. INQUIRY 472, 480-81 (2014). 
These expectations of motherhood result in a model of "good" motherhood as white, middle-class, and heterosexual. ${ }^{133}$

This duty of motherhood extends to the prenatal phase, where there is enormous pressure placed on pregnant women to be the protector of the fetus and make sure it is as healthy as possible. ${ }^{134}$ As a part of this idealized model, women are expected to perform a litany of "correct" behaviors - eat the right foods, sleep in the right positions, and get the right amount of prenatal care - regardless of any barriers such as a lack of education or access to healthcare. ${ }^{135}$ While these behaviors may be in the best interest of the fetus, failing to perform them is not necessarily a crime. ${ }^{136}$ Parents have no legal duty to use their bodies to save their children, ${ }^{137}$ yet society expects this self-sacrifice from pregnant women. Women who do not perform these duties are sometimes judged to have put their own desires before those of their progeny, essentially to have failed as both mothers and women. ${ }^{138}$ States may be using concealment and abuse of a corpse laws to criminalize the actions of those women who diverge from middle-class norms that define "good" femininity or womanhood. ${ }^{139}$ For instance, these statutes are often used against women

\footnotetext{
${ }^{133} \mathrm{Id}$. at 474 .
}

${ }^{134}$ Deborah Lupton, 'Precious Cargo': Foetal Subjects, Risk and Reproductive Citizenship, 22 CRITICAL Pub. Health 329, 330 (2012) (mentioning "the sheer volume and intensity of advice and admonitions expressed in both expert and popular forums to pregnant women to engage in 'reproductive asceticism' that is, to stringently monitor and control their body for the sake of their foetuses").

${ }^{135} \mathrm{Id}$.

${ }^{136}$ For instance, failing to abstain from drug use when pregnant is not a crime in the majority of states. Leticia Miranda et al., How States Handle Drug Use During Pregnancy, ProPublica (Sept. 30, 2015), https://projects.propublica.org/graphics/maternity-drug-policies-by-state [https://perma.cc/6GZ6-LJBN].

137 Julie D. Cantor, Court-Ordered Care: A Complication of Pregnancy to Avoid, 366 NEw Eng. J. Med. 2237, 2240 (2012).

${ }^{138}$ April L. Cherry, Shifting Our Focus from Retribution to Social Justice: An Alternative Vision for the Treatment of Pregnant Women Who Harm Their Fetuses, 28 J.L. \& HeALth 6, 39-40 (2015) (noting that "as a hegemonic ideology, motherhood is reinforced by at least three core beliefs and expectations: (1) that motherhood for women is normal, natural, and desired; (2) that good mothers are altruistic and intensive, which includes the assumption of primary responsibility for the care of their children; and (3) that the women who put their own needs and desires before those of their children are bad mothers who need to be regulated and controlled").

${ }^{139}$ Reva B. Siegel, Abortion as a Sex Equality Right, in Mothers in LaW: Feminist Theory and the LegaL REGUlATION OF MOTHERHOOD, supra note 127, at 56. 
who seem to be ambivalent or unhappy about their pregnancies. ${ }^{140}$ Cases of women who have been charged with concealment crimes can often turn on whether the women were "good mothers," based on their actions while pregnant. ${ }^{141}$ It is also telling that these laws are usually used only against women, ${ }^{142}$ and some states' concealment statutes only apply to women. ${ }^{143}$

\section{B. Disproportionate Impact on Certain Groups of Women}

No matter what the reason states have for criminalizing pregnancy loss, Black women, women of a lower socioeconomic status, and women who are less educated are more likely to experience stillbirths and thus bear a disproportionate part of the burden of this criminalization. ${ }^{144}$ Some of the risk factors which are correlated with higher incidences of stillbirths are race, access to prenatal care (often tied to socioeconomic status), and level of education. ${ }^{145}$ Race especially is highly correlated to fetal death; from 1922 to 1970, the fetal death rate for women of color was consistently about double the rate for white women. ${ }^{146}$ Even to this day, Black women in particular experience stillbirths at approximately twice the rate that white women do. ${ }^{147}$ Although this is probably somewhat due to the interplay of many other factors such as reduced access to

\footnotetext{
${ }^{140}$ See supra Part I.D.

${ }^{141}$ See, e.g., Emma Milne, Concealment of Birth: Time to Repeal a 200-Year Old "Convenient Stop-Gap"?, 27 Feminist Legal StUd. 139, 152-56 (2019) (discussing sentencing hearings for women charged with concealment crimes, where the women were judged on their behavior as mothers as a way to assess their responsibility and character).
}

142 There is one case where a man was charged under Pennsylvania's concealment of a death statute, but application of concealment statutes to men appears to be rare. Chester County Man Charged with Burning Stillborn Baby's Body, Dealing Meth, NBC PHILA. (Oct. 2, 2019),

https://www.nbcphiladelphia.com/news/local/chester-county-man-charged-with-burning-stillborn-babysbody-dealing-meth/219761 [https://perma.cc/9M8J-8HX2].

14311 R.I. Gen. Laws § 11-18-4 (2012); OKLa. Stat. tit. 21, § 863 (2020); Мich. Comp. Laws $§ 750.150$ (2003).

${ }^{144}$ See infra notes $145-151$ and accompanying text.

${ }^{145}$ Darios Getahun et al., Risk Factors for Antepartum and Intrapartum Stillbirth: A Population-Based Study, 196 AM. J. OBSTETRICS \& GYNECOLOGY 499, 499 (2007).

${ }^{146}$ CHUSED \& Williams, supra note 15 , at 285-86.

${ }^{147}$ Ruth C. Fretts, Etiology and Prevention of Stillbirth, 193 AM. J. OBSTETRICs \& GyneCOLOGY 1923, 1926 (2005). 
healthcare, ${ }^{148}$ a study found a significant disparity in fetal death rates between Black and white women even when the women accessed prenatal care. ${ }^{149}$ Regardless of race, lack of prenatal care is associated with significantly higher rates of stillbirth, especially during the gestation period of thirty to thirty-two weeks. ${ }^{150}$ Having less than a high school education is yet another risk factor for stillbirth. ${ }^{151}$ If the laws criminalizing pregnancy loss are equally applied to all women who experience pregnancy loss, then groups that have higher stillbirth rates will bear a greater burden.

Women of color and women of lower socioeconomic status not only suffer a higher number of miscarriages and stillbirths, but prosecutors may also be using their discretion to disproportionately apply criminal laws to these women due to biases and stereotypes. Black women in particular have long suffered from assumptions that they are sexually wanton, careless towards their children, or welfare queens who purposely get pregnant in order to take advantage of taxpayers. ${ }^{152}$ Poor women have also been assumed to be lazy "degenerates" who are the cause of their own misfortunes. ${ }^{153}$ These stereotypes may lead to doctors reporting certain types of women to law enforcement based on the assumption that they have committed a crime, ${ }^{154}$ and they may lead law enforcement and prosecutors to presume guilt when looking at a woman's actions.

\footnotetext{
${ }^{148} I d$.

${ }^{149}$ Anthony M. Vintzileos et al., Prenatal Care and Black-White Fetal Death Disparity in the United States: Heterogeneity by High-Risk Conditions, 99 AM. J. OBSTETRICS \& GyNECOLOGY 483, 485 (2002) (explaining that "although the benefit of prenatal care in reducing fetal death in blacks and whites was of a similar magnitude for most high-risk conditions, the overall disparity in fetal death rates between blacks and whites persisted even in the presence of prenatal care (4.2 versus 2.4 per 1000, respectively)").
}

${ }^{150} I d$

${ }^{151}$ Ruth E. Little \& Clarice R. Weinberg, Risk Factors for Antepartum and Intrapartum Stillbirth, 137 Am. J. EPIDEMIOLOGY 1177, 1180 (1993).

${ }^{152}$ Dorothy Roberts, Punishing Drug Addicts Who Have Babies: Women of Color, Equality, and the Right of Privacy, 104 HaRV. L. Rev. 1419, 1436-44 (1991).

${ }^{153}$ Martha L. Fineman, Images of Mothers in Poverty Discourses, 1991 DuKE L.J. 274, 283-85 (discussing the stigma against poor single mothers due to the implication that they choose to be poor and pass on a "culture of poverty").

${ }^{154}$ Paltrow \& Flavin, supra note 7, at 327 ("Hospital-based health care providers and social workers appear more likely to disclose information about patients of color.”). 
This possibility of disproportionate impact is borne out when looking at data on state action against women based on their pregnancy. A study of women whose pregnancy or pregnancy loss was the basis of an attempted or actual arrest, detention, or forced intervention found glaring patterns in the type of women charged. ${ }^{155}$ Fifty-two percent of the women charged were Black, with particularly large racial disparities in certain states. ${ }^{156}$ In Florida, where only fifteen percent of the population is Black, about threefourths of these cases were brought against Black women. ${ }^{157}$ This is a clear disproportionate application of the law based on race. And about seventy-one percent of all the women charged were likely economically disadvantaged because they qualified for indigent defense. ${ }^{158}$

Another study looked at cases of unassisted birth, where the result was either a stillbirth or a baby which died shortly after birth and the mother disposed of the remains. ${ }^{159}$ The study found a large difference in the punishment meted out, a difference which was based on law enforcement and the public's perception of the women. ${ }^{160}$ Young, privileged, white women were perceived as good people who made a youthful mistake which they could learn from and were usually given light punishments like probation. ${ }^{161}$ Older women, women of color, and low-income women were perceived as inherently bad people and bad mothers who could not change, and they received far harsher sentences as a result. ${ }^{162}$ These are normative judgments that anyone might make - but when they are made by law enforcement officials or prosecutors, these judgments can lead to presumptions of guilt and disproportionate prosecutions of certain groups of women.

\footnotetext{
${ }^{155}$ Id. at $310-12$.

${ }^{156} I d$. at 312 .

${ }^{157} \mathrm{Id}$.

${ }^{158} I d$. at 311 .

${ }^{159}$ Nancy Ehrenreich, Colonization of the Womb, 43 Duke L.J. 492, 517-19 (1993).

${ }^{160} \mathrm{Id}$.

${ }^{161} I d$. (discussing how these women were perceived by law enforcement and the public as "good girls gone bad" or suffering from "criminal warped innocence").

${ }^{162}$ For instance, Sarah Berkeley, a twenty-eight-year-old woman on public assistance who had not known she was pregnant, was arrested after giving birth on the toilet. Her boyfriend called $9-1-1$ as soon as they realized she was giving birth, and testing showed that the fetus was stillborn. She was charged with child endangerment and neglect of a dependent person. She received twenty years in prison. See id.
} 


\section{Implications of Fetal Personhood Ideas}

All groups of women may be vulnerable to prosecution when ideas of fetal personhood take root in society. Charging women with concealment crimes or abuse of a corpse after pregnancy loss can advance ideas of the fetus as a person with the same constitutional rights as a pregnant woman. Justice Blackmun, writing for the majority in Roe v. Wade, declined to give the fetus the rights of a constitutional person and rejected the idea that a post-viability fetus has rights independent of the pregnant woman who is carrying it. ${ }^{163}$ As he noted, "[i]f this suggestion of [fetal] personhood is established . . . the fetus' right to life would be guaranteed specifically by the [Fourteenth] Amendment." 164 Still, there has been a wave of attempts to secure the rights of the fetus as a separate person. ${ }^{165}$ Some of these attempts have been unsuccessful. For instance, activists advocated for a never-adopted constitutional amendment which would include the unborn as "persons" under the Fourteenth Amendment. ${ }^{166}$ Groups in Colorado, Mississippi, and Oklahoma tried to pass ballot measures which would have given full legal rights to fertilized eggs, although those measures all ultimately failed after being rejected by voters. ${ }^{167}$ However, the fetal personhood movement has had some successes

\footnotetext{
${ }^{163}$ Roe v. Wade, 410 U.S. 113, 158 (1973).

${ }^{164}$ Id. at $156-57$.

165 See, e.g., Ala. Code $\S 13$ A-6-1 (2020); Kan. Stat. AnN. § 21-5419 (2020); Miss. Code AnN. § 97-3-37 (2020).
}

166 Glen A. Halva-Neubauer \& Sara L. Zeigler, Promoting Fetal Personhood: The Rhetorical and Legislative Strategies of the Pro-Life Movement After Planned Parenthood v. Casey, 22 FEMINIST FormATIONS 101, 102 (2019).

167 Jason Salzman, Colorado's 'Personhood' Amendment Defeated by Wide Margin, RewIRE News (Nov. 5 , 2014), https://rewire.news/article/2014/11/05/colorados-personhood-amendment-defeated-wide-margin [https://perma.cc/PB23-MHVF] (discussing Amendment 67, rejected by voters, which would have changed the definition of a "person" in Colorado's criminal code to include fetuses and would have likely allowed prosecutors to criminally charge women for recklessness or abuse if they lost their pregnancy); Rich Phillips, Mississippi Voters Reject Anti-Abortion Initiative, CNN (Nov. 9, 2011),

https:/www.cnn.com/2011/11/09/politics/mississippi-election/index.html [https://perma.cc/23CZ-LXUX] (discussing Amendment 26, rejected by voters, which would have defined life in Mississippi law as starting at conception and would have banned abortions, forms of birth control which work after an egg has been fertilized, and even in vitro fertilization techniques which result in the destruction of fertilized eggs); Steve Olafson, Oklahoma Court Rejects Ballot Initiative on “Personhood,” REUTERs (Apr. 30, 2012), https://www.reuters.com/article/us-usa-abortion-personhood/oklahoma-court-rejects-ballot-initiative-onpersonhood-idUSBRE84000H20120501 [https://perma.cc/4UAA-RS64] (discussing how a failed Oklahoma 
in changing laws. Congress passed the Unborn Victims of Violence Act in 2004, which recognized embryos and fetuses as legal victims when they were injured during a crime of violence. ${ }^{168}$ States also adopted fetal personhood language. Kansas, for instance, defines an "unborn child" as a living human organism at any stage from fertilization to birth, and also clarifies that for the purpose of some laws, "human being" and "person" also refer to "unborn children"- essentially stating that a fertilized zygote has many of the same legal protections as an adult human being. ${ }^{169}$ In Georgia, embryos now have "rights and responsibilities under state law." 170 These personhood laws are part of a concerted push to undermine women's reproductive rights. ${ }^{171}$ The sponsor of North Dakota's personhood amendment admitted as much when asked about her bill; she explained " $[\mathrm{w}] \mathrm{e}$ are intending that it be a direct challenge to Roe v. Wade, since Scalia said that the Supreme Court is waiting for states to raise a case." ${ }^{172}$

But personhood ideas can take root in more subtle ways as well. By charging women with crimes like concealing a birth, concealing a death, or abuse of a corpse, prosecutors are invoking statutes that were meant to protect newborn children, not unborn fetuses. ${ }^{173}$ Rather than working to help women who have gone through a traumatic experience, the state is focusing its efforts on protecting the fetuses those women once carried. This

amendment, which would have defined life as beginning at the time of conception and would have defined an embryo as a human being, was struck down by the state supreme court as unconstitutional).

${ }^{168}$ Unborn Victims of Violence Act of 2004, Pub. L. No. 108-212, 118 Stat. 568.

${ }^{169}$ KAN. STAT. ANN. § 21-5419 (2020).

${ }^{170}$ Press Release, Christian News Wire, Georgia Legislature Passes Nation's First Embryo Adoption Law (Apr. 3, 2009), http://www.christiannewswire.com/news/630359951.html [https://perma.cc/Q2BD-R9K6].

${ }^{171}$ Jonathan F. Will, Beyond Abortion: Why the Personhood Movement Implicates Reproductive Choice, 39 AM. J.L. \& MED. 573, 596 (2013) (“'[P]ersonhood proponents openly condemned IUDs, emergency contraception, and RU-486, since each of these are thought to be effective after the sperm has penetrated the egg, either by preventing successful implantation of the fertilized ovum, or by causing the pregnancy to terminate after implantation has occurred. Up for debate was the intended (or potential) impact of personhood on hormonal contraceptives that are used by many women in the United States.").

${ }^{172}$ Laura Bassett, North Dakota Personhood Measure Passes State Senate, HufFington Post (Feb. 7, 2013), http://www.huffingtonpost.com/2013/02/07/north-dakota-personhood_n_2640380.html

[https://perma.cc/UFG6-4CWM]. A state senator who has championed South Carolina's Personhood Act has expressed a similar motivation. Grace Guarnieri, South Carolina 'Personhood Act' that Could Ban Abortions Aims to Overturn Roe v. Wade, NEwsweEK (Feb. 21, 2018), https://www.newsweek.com/south-carolinapersonhood-act-abortions-815131 [https://perma.cc/A82K-RUZV].

${ }^{173}$ See supra Parts I.A.1 and I.B. 
protection of the fetus over the woman has the effect of transforming cultural practices around how we think about fetuses and the rights of pregnant women. When the state begins to treat fetuses like people, society begins to consider them to be people with full constitutional rights. ${ }^{174}$ This mirrors the tactics employed by pro-life groups, who attempt to connect abortion to murder by using images designed to create an association between fetuses and happy smiling babies. ${ }^{175}$

This shift in cultural perceptions and legal language towards fetuses can have widereaching consequences. The most obvious implication is an erosion of abortion rights. But there could also be legal consequences for pregnant women if their fetuses have the same rights as them. For instance, a woman who engages in actions that cause pregnancy loss, even if those actions are unintentional, could be charged with murder. ${ }^{176} \mathrm{~A}$ woman could be criminally liable simply because she wore heels and fell, ate something that made her ill, or smoked a cigarette and later experienced pregnancy loss. ${ }^{177}$ Fetal protection laws can also threaten women's ability to participate in the workforce if their work involves any activity that could be considered risky. ${ }^{178}$ These laws would also likely necessitate that the state investigate every pregnancy loss in order to fully ensure that it was not "caused" by the woman in some way. ${ }^{179}$ This type of fetal protection framework

\footnotetext{
174 Jeannie Suk Gersen, How Fetal Personhood Emerged as the Next Stage of the Abortion Wars, NEw YORKER (June 5, 2019), https://www.newyorker.com/news/our-columnists/how-fetal-personhood-emergedas-the-next-stage-of-the-abortion-wars [https://perma.cc/5UCZ-XHUC] (noting that a state law regulating the disposal of fetal remains "transform[s] cultural practices surrounding the treatment of fetuses, through gestures that suggest they are person-like entities, and point[s] at their rights").
}

175 The anti-abortion group Feminists for Life, for instance, created a poster featuring a "wide-eyed, white infant hooded in a towel and looking straight into the camera" in order to sway public opinion against abortion. See Halva-Neubauer \& Zeigler, supra note 166, at 109.

${ }^{176}$ Valena Elizabeth Beety, Mississippi Initiative 26: Personhood and the Criminalization of Intentional and Unintentional Acts by Pregnant Women, 81 Miss. L.J. 55, 58 (2011).

${ }^{177} I d$. at 61 ("Even if unintentionally harming her unborn child, a mother could be charged with depraved heart murder if she smokes and has a miscarriage or stillbirth, because that unborn child is now a citizen. The same could occur for a range of habits, conditions, actions, or inactions that might cause harm to the unborn child, thus criminalizing the behavior of mothers.").

${ }^{178}$ Linda C. Fentiman, The New "Fetal Protection": The Wrong Answer to the Crisis of Inadequate Health Care for Women and Children, 84 Denv. U.L. REv. 537, 540 (2006).

${ }^{179}$ After Georgia passed a personhood measure, some speculated the measure would allow prosecutors to interrogate any woman who experienced a miscarriage in order to determine if she could be held criminally responsible for the miscarriage. Mark Joseph Stern, Georgia Just Criminalized Abortion. Women Who 
is already in place in some areas. In El Salvador, women who experience pregnancy loss are immediately under criminal suspicion. ${ }^{180}$ The Utah legislature passed the Criminal Homicide and Abortion Revisions Act in 2010, which includes provisions to punish pregnant women who "knowingly" commit an act that could result in miscarriage. ${ }^{181}$ Laws such as these put the state in the position of balancing the rights of the fetus and the woman, as well as determining whose rights gets precedence when they conflict. This is a slippery slope towards complete state regulation of pregnant women, from what they eat to what kinds of jobs they work, all in the name of fetal protection.

\section{Abortion and the Rise of Telemedicine}

Ideas of fetal personhood are intimately tied to the erosion of abortion rights. As discussed in Part II.A, concealment and abuse of a corpse statutes may be used by the state to punish "bad mothers" for their socially undesirable behaviors. ${ }^{182}$ Choosing to terminate a pregnancy is the ultimate rejection of motherhood and femininity; women who do so are thought of as the worst of "bad mothers." 183 Women who seek out abortions are, therefore, vulnerable to criminal prosecution under these statutes, which can be used as a backdoor to punish women for, or deter them from, obtaining an abortion which would otherwise be legal.

Since the Supreme Court ruled in Roe v. Wade that the United States Constitution protects a woman's right to terminate her pregnancy before the point that the state's

Terminate Their Pregnancies Would Receive Life in Prison., SLate (May 7, 2019), https://slate.com/newsand-politics/2019/05/hb-481-georgia-law-criminalizes-abortion-subjects-women-to-life-in-prison.html [https://perma.cc/42DT-33XZ]. Similar concerns were expressed when Colorado attempted to pass a personhood state constitutional amendment. See Salzman, supra note 167.

${ }^{180}$ Elisabeth Malkin, They Were Jailed for Miscarriages. Now, Campaign Aims to End Abortion Ban., N.Y. Times (Apr. 9, 2018), https://www.nytimes.com/2018/04/09/world/americas/el-salvador-abortion.html [https://perma.cc/HTJ3-NM4E].

1812010 Utah Laws 149, 150.

${ }^{182}$ See supra Part II.A.

${ }^{183}$ Abrams, supra note 130, at 180 (discussing how bad mothers are those who act "in ways that reject the inevitability of maternal bonds. Thus, a woman who terminates a pregnancy or becomes a surrogate is by definition a bad mother. The bad mother manifests two similar moral failings common to perceptions of abortion and surrogacy. First, by rejecting her maternal role she abandons her child. Second, a bad mother is one who puts personal concerns before motherhood."). 
interest in the potential life of the unborn becomes compelling, ${ }^{184}$ state governments have been attempting to restrict women's access to abortion. Forty-three states prohibit abortions after a certain time period unless certain exceptions are met. ${ }^{185}$ The Supreme Court deemed such restrictions on abortion constitutional in Planned Parenthood $v$. Casey, as long as the restrictions do not place an undue burden on women seeking an abortion. ${ }^{186}$ States have enacted legislation mandating counseling before abortions, waiting periods before abortions, that abortions after certain time periods must be performed in a hospital, and other forms of restrictions. ${ }^{187}$ Louisiana, for instance, criminalizes the distribution of any drug, potion, instrument, or article for the purpose of inducing an abortion. ${ }^{188}$ However, some states with laws restricting abortion have prohibitions on bringing criminal charges against women who experience the death of their fetus in utero. ${ }^{189}$

One form of abortion is "medication abortion," the use of drugs that can induce an abortion until the tenth week of gestation. ${ }^{190}$ The most common method is the use of two medications - the first blocks progesterone, a hormone required for pregnancy, while the second, taken twenty-four to forty-eight hours later, empties the uterus in a manner

\footnotetext{
${ }^{184}$ Roe v. Wade, 410 U.S. 113, 163 (1973) (“'FF]or the period of pregnancy prior to this 'compelling' point, the attending physician, in consultation with his patient, is free to determine, without regulation by the State, that, in his medical judgment, the patient's pregnancy should be terminated. If that decision is reached, the judgment may be effectuated by an abortion free of interference by the State. With respect to the State's important and legitimate interest in potential life, the 'compelling' point is at viability.").

${ }^{185}$ An Overview of Abortion Laws, GUTTMACHER InsT., https://www.guttmacher.org/statepolicy/explore/overview-abortion-laws [https://perma.cc/22VD-24E8].

${ }^{186}$ Planned Parenthood of Se. Pa. v. Casey, 505 U.S. 833, 879 (1992).

${ }^{187}$ Id. at $880-82$.

${ }^{188}$ LA. STAT. ANN. § 14:88 (2020).

189 See, e.g., ARK. CODE ANN. § 5-61-102(c) (2012) ("Nothing in this section shall be construed to allow the charging or conviction of a woman with any criminal offense in the death of her own unborn child in utero."); see also LA. STAT. ANN. § 14:87(E)(2) (2020) ("This penalty shall not apply to the female who has an abortion."). But see IDAHO CODE § 18-606 (2020) (allowing state to charge any woman "who knowingly submits to an abortion or solicits of another, for herself, the production of an abortion, or who purposely terminates her own pregnancy otherwise than by a live birth").

${ }^{190}$ The Availability and Use of Medication Abortion, KAISER FAM. Found. (June 8, 2020), https://www.kff.org/womens-health-policy/fact-sheet/the-availability-and-use-of-medication-abortion/ [https://perma.cc/2TF4-4WGH].
} 
similar to an early miscarriage. ${ }^{191}$ In 2017 , thirty-nine percent of all abortions in the United States involved the use of medication abortion to induce pregnancy loss. ${ }^{192}$ Likely due to its growing popularity, some states are working to place limitations on medication abortion procedures. For instance, as of October 2020, thirty-two states require that the clinician providing a medication abortion be a physician, and nineteen states have laws that require the clinician providing a medication abortion be physically present during the procedure. ${ }^{193}$ In Iowa, these restrictions were found to be unconstitutional because they placed an undue burden on women seeking an abortion and served to effectively ban the telemedicine provision of abortion medication. ${ }^{194}$

Medication abortion can be provided through telemedicine, which is the use of teleconferencing or other technology to get medical care remotely from a physician or nurse. ${ }^{195}$ More than half of U.S. hospitals use some form of telemedicine, and private insurance records show that use of telemedicine has grown rapidly in the last decade. ${ }^{196}$ Due to the coronavirus pandemic, rules requiring medical providers and patients to be located in the same location have been relaxed, resulting in a large expansion in telemedicine. ${ }^{197}$ The spread of telemedicine is especially important for women because it has the potential to greatly expand and improve access to abortion care, especially in

${ }^{191} I d$.

${ }^{192}$ Rachel K. Jones et al., Abortion Incidence and Service Availability in the United States, 2017, GUTTMACHER INST. (Sept. 2019), https://www.guttmacher.org/report/abortion-incidence-service-availabilityus-2017 [https://perma.cc/KQ8T-X5C8].

${ }^{193}$ Medication Abortion, GUTTMACHER INST., https://www.guttmacher.org/state-policy/explore/medicationabortion [https://perma.cc/H4F4-C4ZS].

${ }^{194}$ Planned Parenthood of the Heartland, Inc. v. Iowa Bd. of Med., 865 N.W.2d 252, 253-54 (Iowa 2015).

195 Telemedicine to Improve Access to Abortion Care, Advancing New StANDARDS IN REPROD. HeALTh, https://www.ansirh.org/research/telemedicine-improve-access-abortion-care [https://perma.cc/QJE4-5WFA].

${ }^{196}$ Improving Access to Abortion via Telehealth, GUTTMACHER InST. (May 16, 2019), https://www.guttmacher.org/gpr/2019/05/improving-access-abortion-telehealth [https://perma.cc/JZA4EQWJ].

${ }^{197}$ See Jane E. Brody, A Pandemic Benefit: The Expansion of Telemedicine, N.Y. TIMEs (May 11, 2020), https://www.nytimes.com/2020/05/11/well/live/coronavirus-telemedicine-telehealth.html [https://perma.cc/2ZUF-AYAW]; see also Anna Louise Sussman, Could Coronavirus Make Telemedicine Abortion the New Normal?, ElLE (May 19, 2020), https://www.elle.com/life-love/a32335002/telemedicineabortion-coronavirus/ [https://perma.cc/284V-FJMU]. 
rural areas. ${ }^{198}$ In 2017, thirty-eight percent of women aged fifteen to forty-four lived in a county in the United States that lacked a clinic facility that provided abortion care. ${ }^{199} \mathrm{In}$ fact, in 2010, more than ten million women lived in counties without a single obstetrician-gynecologist to provide any form of reproductive healthcare, and the demand for these services was forecasted to grow by $2020 .{ }^{200}$ In addition to this lack of providers, women also face financial, transportation, legal, or other barriers that prevent them from accessing an abortion provider. ${ }^{201}$

These factors have led to the growing popularity of telemedicine abortions. Planned Parenthood now offers prescriptions for medication abortion pills through telemedicine in at least ten states, and other abortion providers are following suit. ${ }^{202}$ One organization, which provides abortion pills through telemedicine, had 37,000 patients contact the organization in a little over a year. ${ }^{203}$ It is likely that women facing obstacles in acquiring abortions - or those who prefer a self-managed abortion — will increasingly turn to pills acquired online to induce abortion; ${ }^{204}$ in this way, telemedicine will increase abortion access to women in those states that have successfully driven out most of their abortion

198 Id.

199 Jones et al., supra note 192.

200 Am. Coll. of Obstetricians \& Gynecologists, Comm. on HealthCare for Underserved Women, COMMitTEE OPINION No. 586, at 2 (2014), https://www.acog.org/-

/media/project/acog/acogorg/clinical/files/committee-opinion/articles/2014/02/health-disparities-in-ruralwomen.pdf [https://perma.cc/Z2CH-NR68] ("By 2010, 49\% of the 3,143 U.S. counties [home to 10.1 million women, or $8.2 \%$ of all women], lacked an obstetrician-gynecologist. These predominantly rural counties exist in all states, but are particularly prevalent in the central and mountain west states."); Timothy M. Dall et al., Estimated Demand for Women's Health Services by 2020, 22 J. WoMEN's HeALTH 643, 645 (2013) (stating that "overall patient demand for ob-gyn services in the United States is forecast to grow by $6 \%$ between 2010 and 2020").

${ }^{201}$ Ushma D. Upadhyay \& Daniel Grossman, Telemedicine for Medication Abortion, 100 CONTRACEPTION 351,351 (2019).

${ }^{202}$ Improving Access to Abortion via Telehealth, supra note 196.

203 According to its founder, Aid Access shipped 7,000 abortion pills in a year. Irin Carmon, Abortion After the Clinic, Cut (Nov. 11, 2019), https://www.thecut.com/2019/11/future-abortion-accessamerica.html\#_ga=2.245128838.2057903244.1573613445-1736965012.1567467828 [https://perma.cc/SKZ4-ENZ4].

204 Id. 
providers through restrictive regulations. ${ }^{205}$ Unfortunately, while use of telemedicine has increased significantly during the coronavirus pandemic, access to medication abortion through telemedicine has not been similarly expanded due to a multitude of regulations. The Food and Drug Administration (FDA), for instance, places limitations on receiving abortion medication by mail. ${ }^{206}$ One way around this restriction is through use of the TelAbortion research program, which has a special arrangement with the FDA that allows it to continue operating. ${ }^{207}$ The program involves medical professionals first consulting with women through teleconferencing, mailing the abortion medications to the patients, and then performing follow-ups. ${ }^{208}$ However, seventeen states regulate telemedicine abortion, ${ }^{209}$ and any woman in those states would have to travel to another state without restrictions to take part in the videoconference consultation and to pick up the medication. ${ }^{210}$ Researchers and healthcare providers in two locations have also created a protocol that allows patients to determine eligibility for abortion medication via telehealth and take the pills at home. ${ }^{211}$ But since the pills must be picked up from the clinic, this method is only accessible to a small number of women. ${ }^{212}$

\footnotetext{
${ }^{205}$ For example, in Kentucky, every abortion facility must enter into a written agreement with a hospital and an ambulance service. Ky. REv. StAT. ANN. § 216B.0435 (West 2020). In South Dakota, any licensed abortion facility must comply with regulations regarding personnel, sanitation, and quality assurance. S.D. CODIFIED LAWs § 34-23A-51 (2020). Regulations in South Dakota also dictate the size, floor surface, and lighting for facilities. S.D. ADMIN. R. 44:67:05:02 (2020). In Mississippi, Department of Health regulations specify that abortion facilities must be in an "attractive location," that doors must be at least three feet wide, and that no part of the facility can be rented or leased for another purpose. 15-016 Miss. CoDE R. $\S \S$ 044.31.1-44.31.12 (LexisNexis 2020). These states each contained only one abortion clinic as of 2017, a decrease from previous years. See Jones et al., supra note 192.
}

${ }^{206}$ Amrutha Ramaswamy et al., Medication Abortion and Telemedicine: Innovations and Barriers During the COVID-19 Emergency, KAISER FAM. FOUND. (June 8, 2020), https://www.kff.org/policy-watch/medicationabortion-telemedicine-innovations-and-barriers-during-the-covid-19-emergency [https://perma.cc/LWL6$\mathrm{X} 3 \mathrm{DD}]$.

${ }^{207}$ Pam Belluck, Abortion by Telemedicine: A Growing Option as Access to Clinics Wanes, N.Y. TIMES (Apr. 28, 2020), https://www.nytimes.com/2020/04/28/health/telabortion-abortion-telemedicine.html [https://perma.cc/5LPP-V7TZ].

${ }^{208} I d$

${ }^{209}$ Improving Access to Abortion via Telehealth, supra note 196.

${ }^{210}$ Belluck, supra note 207.

${ }^{211}$ Ramaswamy, supra note 206.

${ }^{212} I d$ 
States have been taking action to stop women from using telemedicine methods in hopes of controlling women's exercise of their reproductive rights. For instance, a woman was sentenced to nine to eighteen months in jail for helping her teenage daughter order abortion pills online. ${ }^{213}$ Another woman was arrested in Georgia after taking medication abortion pills she ordered online that induced a stillbirth. ${ }^{214}$ This attempt was eventually unsuccessful; the state was later forced to release her because she had not broken any Georgia laws related to terminating her pregnancy. ${ }^{215}$ States which do not have statutes allowing them to directly prosecute women for this method of abortion may increasingly rely on statutes they do have, such as those criminalizing concealment of a birth or abuse of a corpse, as a way to deter women from ending their own pregnancies. After all, women who take advantage of telemedicine to procure medication abortions will likely choose to take the medication in the comfort of their own home, rather than in a medical setting, ${ }^{216}$ and may be left with the confusing responsibility of reporting and properly disposing of the remains.

The case studies in Part I.D show that women can and do get arrested for concealment or abuse of a corpse after experiencing pregnancy loss at home, even if they later take the remains to the hospital. ${ }^{217}$ As discussed in Part I.A.1, many state concealment laws do not specify the amount of time women have to report their

${ }^{213}$ Emily Bazelon, A Mother in Jail for Helping Her Daughter Have an Abortion, N.Y. TiMES MAG. (Sept. 22, 2014), https://www.nytimes.com/2014/09/22/magazine/a-mother-in-jail-for-helping-her-daughter-havean-abortion.html [https://perma.cc/U32U-634M].

${ }^{214}$ Jenny Jarvie, Murder Charge Dropped Against Georgia Woman Who Took Pills for Abortion, L.A. TIMES (June 10, 2015), https://www.latimes.com/nation/la-na-abortion-murder-20150611-story.html.

${ }^{215} I d$. States do have laws which would criminalize self-inducing an abortion from pills ordered online. In Indiana, Purvi Patel was found guilty of feticide through illegally inducing her own abortion. The state found text messages where Patel discussed buying abortion pills online. The prosecutor said that under the state law, an unsuccessful attempt to end a pregnancy could be classified as feticide. Emily Bazelon, Purvi Patel Could Be Just the Beginning, N.Y. Times (Apr. 1, 2015), https://www.nytimes.com/2015/04/01/magazine/purvi-patel-could-be-just-the-beginning.html [https://perma.cc/4VK9-VDYA].

${ }^{216}$ Carmon, supra note 203 (quoting Jill Adams, executive director of the nonprofit If/When/How:

Lawyering for Reproductive Justice, as saying, "People throughout the world, including here in the U.S., have been since the dawn of time ending their own pregnancies. . . And since the advent of abortion pills, they've been doing it safely and more effectively. It's no longer the Chicken Little narrative, where if you pass restrictions, clinics will close, people will be forced to take matters into their own hands, and its certain death and destruction from there. Instead, abortion will become even less accessible, and some people will self-manage abortion and most of them will be perfectly fine.").

${ }^{217}$ See supra Part I.D. 
pregnancy loss (or who to report to) before they can be charged with a crime. ${ }^{218}$ As a result, women who take medications at home to induce an abortion could be criminally liable for concealment of a birth or death under these vague statutes. Even if a woman tries to report her pregnancy loss in order to comply with state law, pregnancy loss before twenty weeks may just look like tissue and fluid rather than an identifiable corpse. ${ }^{219}$ The Massachusetts statute criminalizing concealment of a death of a child, for instance, only requires that the "issue" be born out of wedlock. The statute does not specify how old the issue must be before the requirement applies and does not require any intent to hide the manner in which the issue died. ${ }^{220}$ The state could easily argue that this law applies to a woman who took doctor-prescribed medication abortion pills in her first trimester of pregnancy without immediately reporting her pregnancy loss.

Similarly, the state could criminally charge a woman with abuse of a corpse for disposing of the remains of her abortion rather than taking them to a hospital, even if she was unaware of any requirement to do so. ${ }^{221}$ Even if states do not use these statutes to specifically target women who choose to end their pregnancy with medication obtained through telemedicine, the existence of these previous cases can function as a deterrent. While women might have been previously unaware of state laws regulating their conduct after pregnancy loss, attention to the possibility of criminalization grows as the number of high-profile arrests increases. And as awareness grows about women who have been arrested for natural or medication-induced miscarriage or stillbirth, pregnant women may be dissuaded from using medication to induce abortion. ${ }^{222}$ In this way, states can erode abortion rights and discourage the use of abortion services without even directly regulating abortion.

\footnotetext{
218 See supra Part I.A.1.

219 What Does a Miscarriage Look Like?, HeALTHLINE (Mar. 27, 2019), https://www.healthline.com/health/pregnancy/what-does-a-miscarriage-look-like [https://perma.cc/X9QT$8 \mathrm{~B} 44$ ] (stating that miscarriage symptoms may include bleeding and the passage of tissue, fluid, or other products).

${ }^{220}$ MASS. Gen. LAwS ch. 272, § 22 (2020).

${ }^{221}$ See, for example, the case of Michelle Greenup, discussed supra at notes 99-104 and accompanying text.

${ }^{222}$ For instance, Jennifer Whalen's arrest was written about in an article in The New York Times Magazine which received nearly 800 comments online. As this case and others like it get media attention, awareness grows about the legal risks women are taking on when choosing a self-managed abortion. See Bazelon, supra note 213.
} 


\section{A Way Forward}

Given the possible repercussions on women's rights and the burden on individual women when concealment and abuse of a corpse statutes are used to criminalize pregnancy loss, states should find another avenue to address their concerns. As this Part argues, a modernization of state laws or a paradigm shift to a public health framework each presents a viable alternative to criminal prosecution. Part III.A discusses how state statutes can be modified, while Part III.B discusses how increased education and access to medical care can reduce pregnancy loss and ensure that women who suffer pregnancy loss do not act in a way that might make them criminally liable.

\section{A. Updating the Legal Framework}

Current state concealment statutes are flawed and should be updated to reflect modern realities and concerns. At a minimum, states should clarify reporting requirements for stillbirths and miscarriages. As Part I.A.2 discusses, many state laws criminalizing the concealment of births or deaths are not explicit on what actions a woman can take after experiencing pregnancy loss so that she is not criminally liable. ${ }^{223}$ An ideal clarification would include information on what triggers a reporting requirement, who is required to report, to whom they are required to report, and the time period they have to report the pregnancy loss. States should also follow the Supreme Court's logic in Lambert $v$. California, which held that it is a violation of due process to criminally prosecute someone for failing to register when she was unaware of her registration duty. ${ }^{224}$ Similarly, states should not criminally prosecute women for failing to report their stillbirths if they are unaware of this duty.

States could alternatively follow Virginia's lead and clarify that these statutes do not apply to women who have experienced pregnancy loss. ${ }^{225}$ As discussed previously, these statutes are largely obsolete due to modern medical testing and are based on sexist and

\footnotetext{
${ }^{223}$ See supra Part I.A.2.

${ }^{224}$ In this case, a woman was arrested for violating a Los Angeles ordinance which required felons to register if they were staying in the city for more than five days. She argued that she was not aware of the ordinance and it would be a violation of due process to penalize her. The Court ruled that not knowing about a law can be a defense if the law punishes an omission and the offense was malum prohibitum. Lambert v. California, 355 U.S. 225, 229 (1957).

${ }^{225}$ See Opinion Letter No. 18-023 from Mark Herring, supra note 33.
} 
old-fashioned assumptions about women. ${ }^{226}$ Anne Bynum's case demonstrates that women can be charged with these crimes after a natural pregnancy loss, even if they seek out medical help and are forthcoming with their doctors. ${ }^{227}$ States may argue that these statutes are necessary to punish women who commit infanticide but are able to hide or destroy the remains well enough that the infanticide cannot be proved. However, statutes criminalizing abuse of a corpse can be used for this small subset of cases. For example, Brooke Skyler Richardson, who was suspected of infanticide and burning the corpse of her newborn, was acquitted of murder but convicted of gross abuse of a corpse. ${ }^{228}$ But states should read abuse of a corpse statutes narrowly and require intent for gross mutilation. $^{229}$

Unfortunately, since concealment laws have been on the books for centuries, it appears that states have little impetus to change them. Women could try to force a change by challenging the constitutionality of the laws on equal protection grounds. Many state statutes only criminalize the actions of women, ${ }^{230}$ including some that only criminalize the actions of unmarried women. ${ }^{231}$ Under the Supreme Court's jurisprudence addressing sex discrimination, states would have to show that these laws are substantially related to an important government interest. ${ }^{232}$ But even if these discriminatory statutes are overturned, there are plenty of other concealment statutes that are facially neutral and may withstand the court's scrutiny. ${ }^{233}$ A more immediate and comprehensive solution to this issue may be to look at it through a reproductive justice lens, focusing on supporting women and providing services so that they feel comfortable seeking out medical attention and don't feel like they need to conceal their pregnancies.

\footnotetext{
${ }^{226}$ See supra Parts I.A.1 and II.A.

227 See supra Part I.D.

${ }^{228}$ Brittany Shammas \& Meagan Flynn, Teen Acquitted of Killing Her Baby Says She's 'Forever Sorry,' WASH. Post (Sept. 13, 2019), https://www.washingtonpost.com/nation/2019/09/13/teen-said-she-buried-herstillborn-baby-backyard-after-prom-she-was-just-acquitted-murder/ [https://perma.cc/Y2B7-CUZG].

229 See supra Part I.B.

${ }^{230}$ See, e.g., OKLA. STAT. tit. 21, § 863 (2020); Mich. COMP. LAWS $§ 750.150$ (2003).

23111 R.I. GEN. LAws $§ 11-18-4$ (2012); Мich. COMP. LAws $§ 750.150$.

${ }^{232}$ United States v. Virginia, 518 U.S. 515, 533 (1996).

${ }^{233}$ See, e.g., Haw. Rev. Stat. § 709-901 (2020); Nev. Rev. Stat. § 201.150 (2020).
} 


\section{B. Shifting from Retribution to Reproductive Justice}

Because criminal punishment can often be counterproductive and inappropriate, the most successful solution might involve thinking outside of the structure of criminal law. ${ }^{234}$ Since medical care during pregnancy and after pregnancy loss is in the best interests of both individual women and society as a whole, it is important to encourage women to seek out that care. Noted public health scholars Peter Old and Jonathan Montgomery argue that "enforcing social responsibility through the threat of punishment is ... probably counterproductive. It alienates those with disease and discourages them from seeking medical help." ${ }^{235}$ From a public health perspective, it is better to provide access to voluntary health care measures rather than enforcing health through coercive action by the state, because this helps maintain individual dignity. ${ }^{236}$ As discussed in Part II.B, criminalization of pregnancy loss is an issue that disproportionately affects women of color and women of lower socioeconomic status. ${ }^{237}$ Women in these groups often are distrustful of the medical system, ${ }^{238}$ and they may lack the means and education about their healthcare options to achieve self-determination in their reproductive decisions. These women are among the most vulnerable in our society because they are pregnant, lack access to resources, and are subject to a culture that judges them as bad mothers. ${ }^{239}$ The fear of prosecution will only further isolate these women and foster greater distrust of the system. The best way to reach women may be through a reproductive justice framework - by supporting their right to maintain personal bodily autonomy, have children or not have children, and parent the children they have in safe and sustainable

\footnotetext{
${ }^{234}$ See supra Part I.D for case examples.

${ }^{235}$ Peter Old \& Jonathan Montgomery, Law, Coercion, and the Public Health, 304 Brit. MED. J. 891, 891 (1992) (discussing how effective disease control depends on working with those who are infected, rather than seeing the infected as the enemy).

${ }^{236}$ Cherry, supra note 138, at 59 (discussing how "the value of dignity should be articulated by voluntariness, offering assistance and access to resources on a non-compulsory basis, not through the coercion of the criminal law").

${ }^{237}$ See supra Part II.B.

${ }^{238}$ Armstrong et al., supra note 73 , at 1287.

${ }^{239}$ Cherry, supra note 138, at 56 ("Pregnant women who are depressed and suicidal, who are addicted to drugs and alcohol, and those who lack the resources to procure a legal abortion . . . are among the most vulnerable in American society. Not only are they female, and hence subject to a culture that devalues them as women and demonizes them as bad mothers, but they also are often poor and undereducated, and as a result, have few social resources available to them.").
} 
communities. ${ }^{240}$ This can involve analyzing power systems and targeting interventions, such as education and increased health care access, on the most marginalized populations.

First, states can work to increase general awareness about pregnancy outcomes and what women should do when they experience pregnancy loss. State departments of health can spearhead public information campaigns, although it may also be helpful to coordinate with the CDC. ${ }^{241}$ An effective campaign would be evidence-based and draw on mass media campaign principles to educate women about the risk factors and warning signs of pregnancy loss and when to seek medical intervention or report their fetal death. ${ }^{242}$ These campaigns should be part of an integrated approach to pregnancy loss and be sustained over a period of years in order to achieve an impact in the broader population. ${ }^{243}$ Australia, for example, announced a three-million-dollar stillbirth awareness campaign in order to demystify stillbirth, educate the public about the risks of stillbirth, and encourage conversations about stillbirth as a public health issue. ${ }^{244}$ Some states are starting to implement similar limited programs to increase awareness of pregnancy loss. The Ohio Department of Health and the West Virginia Department of Health and Human Resources have each partnered with a nonprofit for stillbirth

\footnotetext{
${ }^{240}$ See Reproductive Justice, SISTER SONG, https://www.sistersong.net/reproductive-justice [https://perma.cc/RZX2-CRUL] (defining reproductive justice).

${ }^{241}$ The CDC has developed many public health campaign resources that are available for use by state and local health departments and community organizations. For instance, the CDC makes available resources for a diabetes awareness campaign, with information on prediabetes, diabetes prevention, and diabetes management. Featured Campaigns, Ctrs. For Disease Control \& Prevention, https://www.cdc.gov/healthcommunication/campaigns/index.html [https://perma.cc/P6KJ-2REP].

${ }^{242}$ There may be limited benefits from such campaigns if focused solely on risk factors, because many of the risk factors for pregnancy loss are complex and difficult to modify (such as race, obesity, and advanced maternal age). Additionally, it is possible that the campaign would have the negative effect of increasing anxiety among pregnant women. This could result in increases in miscarriage risk due to stress or women seeking out medically unnecessary care. Vicki Flenady et al., Stillbirth Prevention: The Challenges of Public Campaigns, 125 BJOG 253, 253 (2017).

${ }^{243} I d$.

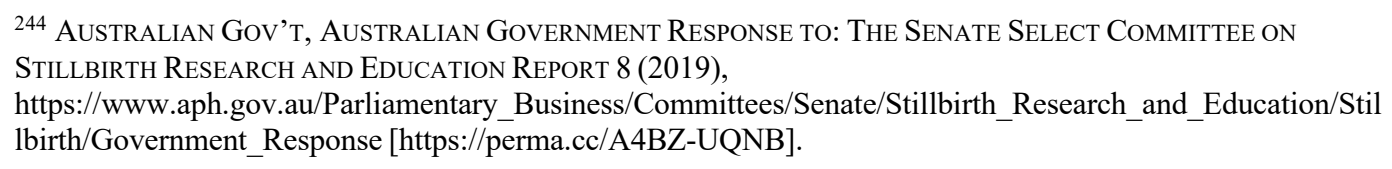


prevention public awareness campaigns. ${ }^{245}$ The campaigns are focused on educating women in the third trimester of pregnancy on how to track fetal movements and detect if there are any changes. ${ }^{246}$ Through the campaigns, women have access to educational materials and a mobile application which helps track fetal movement. ${ }^{247}$ These state campaigns could be broadened to include information about miscarriage, healthcare interventions, and pregnancy loss reporting requirements.

Second, states can begin to integrate information about pregnancy loss into high school sex education classes. The U.S. Department of Health and Human Services estimates that fifteen percent of teenage pregnancies end in miscarriage, ${ }^{248}$ so early intervention may be crucial in reducing the instances of concealment or abuse of a corpse. Because so many states teach abstinence-only sex education, teenage girls in particular may not notice the signs of pregnancy, may be shocked when they experience a miscarriage or stillbirth, and may be unaware of how to react. ${ }^{249}$ These education programs should particularly address the early stages of pregnancy and encourage students to seek out medical care and other resources if they experience any symptoms of pregnancy.

Finally, states can increase the low-cost prenatal and postnatal care options available to pregnant women. As mentioned in Parts II.A and II.B, a lack of prenatal medical care is risk factor for stillbirth. Women who lack access to affordable healthcare may be more likely to conceal their pregnancies or decline to seek out medical care when experiencing

\footnotetext{
${ }^{245}$ Press Release, Ohio Dep’t of Pub. Health, Stillbirth Prevention Public Awareness Campaign Launches in Ohio (June 5, 2019), https://odh.ohio.gov/wps/portal/gov/odh/media-center/odh-news-releases/stillbirthprevention-public-awareness-campaign [https://perma.cc/A4TV-GH3H]; Wendy Holdren, Stillbirth Prevention Public Awareness Campaign Kicks Off, Register-Herald (Aug. 6, 2019), https://www.registerherald.com/health/stillbirth-prevention-public-awareness-campaign-kicks- off/article_710d013d-456a-54a4952e-8f4d92fflb4b.html [https://perma.cc/HVR2-AQXF].

${ }^{246}$ See supra note 245 and accompanying text.

${ }^{247}$ See supra note 245 and accompanying text.

${ }^{248}$ Kristin Toussaint, Why Miscarriages Should Be in All Sex-Education Plans, TeEn Vogue (Apr. 18, 2019), https://www.teenvogue.com/story/why-miscarriages-should-be-in-all-sex-ed-lesson-plans [https://perma.cc/85DJ-XFCL].

${ }^{249}$ For example, Chelsey Hunt didn't have comprehensive sex education classes in her Utah high school and was therefore shocked to see blood and tissue one day when she went to the bathroom. Only after researching on the internet did she realize she had experienced a miscarriage. $I d$.
} 
pregnancy loss. ${ }^{250}$ An increase in the availability of medical care may reduce the incidence of pregnancy loss, and once women develop a positive relationship with a healthcare professional, they may feel more comfortable seeking out medical care after experiencing pregnancy loss. Currently, Medicaid covers pregnant women whose income is at or below $133 \%$ of the federal poverty level. ${ }^{251}$ Among the services covered are care related to the pregnancy, delivery, and any complications that occur up to sixty days postpartum. ${ }^{252}$ States should extend this coverage to a greater number of women, and perhaps include coverage for pregnancy classes and other educational activities, so that women are fully informed about their pregnancies. This would likely be the most impactful intervention and would help safeguard the lives of both women and their fetuses.

\section{CONCLUSION}

States are using concealment and abuse of a corpse statutes to criminalize the behavior of women who experience normal pregnancy loss. This criminalization disproportionately affects certain groups of women and it will likely have longstanding consequences on the rights of women during pregnancy. By moving away from a punitive framework and towards a public health framework, states can ensure that actual justice is achieved. After all, the state's greatest interest is ensuring a healthy mother, healthy child, and successful delivery. Criminalizing women's behavior after stillbirth or miscarriage does not serve those ends. Instead, states can meet these goals by removing the fear of prosecution, increasing access to medical services, and educating women about how to appropriately deal with pregnancy loss.

\footnotetext{
${ }^{250}$ See supra Parts II.A and II.B.

${ }^{251}$ Medicaid for Pregnant Women, AM. PREGNANCY Ass'N, https://americanpregnancy.org/first-year-oflife/medicaid-for-pregnant-women/ [https://perma.cc/L7LB-5MGH].

${ }^{252} I d$
} 